\title{
Election Report: the Berlin Land Election 2006
}

This article examines the 2006 Berlin Land election, including the election campaigns of the main parties, the results, and the process of post-election coalition formation. While few doubted that the SPD would emerge as the largest party, and that the highly popular Klaus Wowereit would continue as Berlin's governing mayor; the big questions were what coalition he would lead and whether Berliners would vote for a continuation of the (initially controversial) red-red coalition comprising the SPD and the Left Party.PDS.

The 2001 Land election marked a turning point in the politics of post-unification Berlin. Eberhard Diepgen, governing mayor of the city since 1984 (apart from for one year during which the Berlin Wall fell), was removed from office following a bank scandal involving the most senior figures of the Berlin CDU. Shortly after these dramatic events an early election was held to elect a new Land parliament and senate. The drama of the 2001 election was heightened by the personalities involved: the flamboyant and openly gay Klaus Wowereit as Spitzenkandidat for the SPD; the young entrepreneur Frank Steffel for the CDU; and the charismatic Gregor Gysi for the PDS. The outcome was equally dramatic: emerging as the largest party, the SPD controversially chose to form a coalition with the PDS. While 'red-red' coalitions had already existed in the new Länder, this development in the Federal Republic's only 'east-west' Land was further recognition of the PDS as a normal member of the German party system. ${ }^{1}$

In contrast to 2001 the 2006 Land election was rather a routine affair. Contrary to many predictions the 'red-red' coalition had endured, and its term in office was relatively smooth and uneventful, in spite of tough decisions regarding cuts in public expenditure. The only dramatic event had been the resignation of Gysi from the Berlin Senate shortly after the election, following a fairly trivial allegation of misconduct which many believed was merely a pretext to enable Gysi to exit the rather mundane world of Land politics, with the intention of reappearing on the federal stage at a later date. Meanwhile Wowereit swiftly acquired great personal popularity and was seen by many as the embodiment of the new Berlin, one of Europe's most diverse and vibrant cities, which he famously described as 'poor but sexy'. The big problem for the parties in opposition, especially the CDU, was how to approach the 2006 election, given Wowereit's popularity, and the fact that the initially controversial red-red coalition now hardly seemed controversial at all.

\section{THE ELECTION CAMPAIGNS}

The 2006 election campaign period was widely regarded as rather dull compared with 2001, and was dominated by Land issues, such as free day-care for children and proposals for a comprehensive school system. Unlike past elections, for the media, this election was more a contest between 'red-red' and 'red-green' than one between the SPD and CDU.

Under the slogan 'Konsequent für Berlin' the SPD's election campaign was heavily focused on it its greatest asset: Wowereit himself, whose personal rating was consistently 
higher than that of his party. Although technically a west Berliner, many commentators regarded him as a unifying figure who transcended both halves of the city, ${ }^{2}$ and even political opponents, such as the Green Spitzenkandidatin concurred with this view. ${ }^{3}$ However, for many of his critics 'Wowi' was a work-shy 'party animal' who enjoyed Berlin's nightlife more than his day job, although this allegation seemed to do little to damage his reputation. Even the veteran SPD supporter, Günther Grass, joined the party's initiative 'Wir für Wowi' in spite of recent revelations about his past. ${ }^{4}$ However the candidate-focused campaign, reputed to have cost $€ 1.4$ million, ${ }^{5}$ detracted from Berlin's continuing problems, most notably the capital's debts of around $€ 63$ billion $^{6}$ and unemployment of 17 per cent. $^{7}$

From the start polls predicted that the SPD would be the largest party in the Berlin parliament, and the party leadership kept its options open regarding possible coalition constellations, although Wowereit ruled out an Ampelkoalition and a grand coalition. However the media suspected that he and other leading figures in the SPD had a preference for 'red-red' over 'red-green' and or any other variations. ${ }^{8}$

For the Left Party.PDS the years in government in Berlin were rather more turbulent than for their senior coalition partner. Firstly, as mentioned above, there was the resignation of Gregor Gysi as finance senator. The party's remarkably good performance in both halves of the city at the previous Land election had largely been attributed to Gysi, the Spitzenkandidat. The second blow was the party's disastrous performance at the 2002 federal election. While the federal party's alliance with the (largely western German) Wahlalternative Arbeit und Soziale Gerechtigkeit (WASG) to form the Left Party prevented a repeat of this catastrophe in the 2005 federal election, at the time of the 2006 Berlin Land election no formal merger of the two groups had taken place and the Berlin WASG decided to stand against the Left Party.PDS in the city's Land election. This provided a more radical alternative for former PDS voters who were dissatisfied with the party's role in the Land government, especially those in the west of the city who had supported the PDS in 2001 for the first (and possibly the only) time.

For the 2006 Berlin Land election the Left Party.PDS chose finance senator, Harold Wolf, as its Spitzenkandidat. Wolf, once active in the Greens/Alternative List in the old West Berlin, was seen by many as typical of the pragmatic leadership of the Berlin PDS, ${ }^{9}$ but was hardly the crowd puller his predecessor had been. The Left Party.PDS reputedly spent $€ 750,000$ on their election campaign ${ }^{10}$ under the slogan 'Berlin bewegt' (Berlin is moving), and campaigned for a second term for the 'red-red' coalition which they portrayed as 'a senate which has the whole city in view' ${ }^{11}$ While the party had initially lost support in the early years of the coalition due to cuts in public spending, the departure of Gysi, and the loss of its Bundestag Fraktion in 2002, the Berlin party appeared to have overcome these difficulties and was able to conduct its campaign based on its track record as a sensible and reliable coalition partner. Its image as a 'normal' party with realistic policies was further enhanced by the challenge from the WASG who appeared extreme and utopian in comparison. With victory for the SPD almost a foregone conclusion, the big question was whether the Left Party.PDS or the Greens, or even both, would win the second prize as junior coalition partner.

For the CDU the main issue was who would be the sacrificial lamb to challenge Klaus Wowereit in a contest polls predicted they could not win. In 2001, following the departure of the party's old guard, Eberhard Diepgen and Klaus Landowsky, a double act 
who had dominated the party since the early 1990s, the CDU chose a new face to lead them into the Land election of the same year, namely the 38 year old Frank Steffel. But the election was a disaster, producing the Berlin party's worst ever result. Since then they had been preoccupied with personnel problems, and short of credible candidates, chose Friedbert Pflüger to take on the unenviable task of Spitzenkandidat in 2006. Pflüger was a 51 year old Bundestag MP from Lower Saxony, which may have been a disadvantage right from the start in a city with a strong sense of local pride. But whoever had been chosen, doubts remained as to whether voters were ready to trust a party which had been totally introverted for the past five years. The CDU spent $€ 750,000$ on its campaign ${ }^{12}$ with the slogan 'Berlin kann mehr' (Berlin can do more), a response to Wowereit's claim that Berlin was 'poor but sexy'. ${ }^{13}$ In contrast to the SPD's campaign material, the CDU's hardly featured their Spitzenkandidat, with no photos or personal statements by him in the manifesto. ${ }^{14}$ On his personal website Pflüger sought to convince voters of his commitment to overcoming social divisions in the capital, and of his leadership qualities based on his experience as foreign policy advisor for the CDU/CSU and as parliamentary secretary in the defence ministry since the 2005 Bundestag election. ${ }^{15}$ Compared with previous CDU election campaigns, anti-PDS rhetoric was toned down, since after five years in government the party was no longer the pariah it once was, (especially in the eyes of many CDU supporters in West Berlin). Because a centre-right coalition looked unlikely according to opinion polls, Pflüger did not rule out the possibility of a 'Jamaica coalition', ${ }^{16}$ but realistically the party's main objective was simply to do better than in 2001.

Alliance 90/the Greens waged a clear red-green election campaign, as their campaign slogan made clear: 'Grünwählen, bevor Sie rot sehen: BerlinGrün' (Vote Green before you see red). The Greens had not been part of the Berlin senate since 1990, but after a strong performance in the capital at the federal election a year earlier, and with the Left Party.PDS unlikely to repeat its 2001 performance, there were grounds for optimism. Spitzenkandidatin, Franziska Eichstädt-Bohlig (a Berlin Bundestag MP) did not completely rule out a red-red-green coalition, but was far less keen on an Ampelkoalition or 'Jamaica coalition'. ${ }^{17}$ The campaign (costing an estimated $€ 450,000^{18}$ ) aimed to portray the Greens as a modern 'Großstadtpartei' and focused heavily on their Spitzenkandidatin. The once radical party even produced a leaflet about her for insertion in the mainstream women's magazine Brigitte. ${ }^{19}$

The FDP returned to the Berlin parliament in 2001 after two parliamentary terms with no MPs. They spent $€ 300,000$ on their campaign, ${ }^{20}$ with the slogan 'Berlin kann nicht warten' (Berlin can't wait). But the prospects for a role in government were bleak, with little chance of victory for the CDU and too many other parties vying for the coveted position of junior coalition partner for the SPD. The only prospect appeared to be a 'Jamaica coalition' but as mentioned above, the Greens were known to have little enthusiasm for this option.

\section{THE ELECTION RESULTS ${ }^{21}$}

As predicted the SPD emerged as the largest party once the votes were counted, but there were some surprises, namely the scale of the losses for the Left Party.PDS, and the share of the vote taken by small parties (see Table 1). There was also a substantial fall in 
turnout, from 68.1 per cent in 2001 to 58 per cent in 2006, confirming that this election had failed to motivate voters compared with the dramatic election five years earlier. As with previous elections in the reunited capital, turnout was lower in the east of the city (53.8 per cent) compared with the west (61.1 per cent).

Although clearly the victor, the SPD's share of the vote only rose from 29.7 per cent in 2001 to 30.8 per cent in 2006. The party experienced a slight drop in support in west Berlin (from 33.7 per cent to 31.4 per cent), but increased its vote share in the east (from 23.2 per cent in 2001 to 29.8). However the party's share of the seats in the Berlin parliament rose from 44 to 53 since the party won 40 of the 78 direct mandates, 14 more than in 2001. The SPD could also claim more than any other party to be rooted in the whole of the city, with very little difference in its vote share in the east and west (see Table 2). The party's decision to focus its entire campaign on the hugely popular 'Wowi' had paid off, but it also benefited from a weak challenge from the CDU and from the disappointment of many former PDS voters.

\section{TABLE 1}

\section{TABLE 2}

Also with something to celebrate were Alliance 90/the Greens, who were the only party to increase their total number of votes polled (Zweitstimmen) in spite of the dramatic fall in turnout. ${ }^{22}$ They increased their vote-share from 9.1 per cent to 13.1 per cent and won an impressive five direct mandates, compared with just one in 2001, taking two seats from the Left Party.PDS and two from the SPD. Their share of seats in parliament rose from 14 to 23. The scale of the increase in support was mirrored across the city, rising from 11.1 per cent to 14.8 per cent in the west, and from 5.9 to 10.5 per cent in the east, which strengthened the party's claim to be rooted in the whole of Berlin, although it remained an inner-city party, with support peaking at 26.6 per cent in its stronghold, Friedrichshain-Kreuzberg. The increase in Green support in areas of eastern Berlin such as Friedrichshain and Pankow may be attributed to the fact that these areas are popular with so-called Neuberliner originally from western Germany. ${ }^{23}$ The Greens also benefited from voters who wanted to keep the SPD in power but without the Left Party.PDS as coalition partner. However, in terms of voter profile, Berlin's Landeswahlleiter found limited support for the Greens among both first time voters and older voters. $^{24}$

The CDU failed even to reach its modest objective of improving on its dismal performance in 2001, its vote-share falling from 23.8 per cent, to 21.3 per cent. Losses were even greater in the west of the city than the east, falling from 30.8 per cent to 27.7 per cent in the former, and from 12.4 per cent to 11.4 per cent in the latter. However, in terms of seats, the party gained two, earning a total of 37, and maintained its share of direct mandates (19). The CDU's poor performance appeared largely to be a result of its little-known candidate who simply could not compete with Wowereit. Also, according to the Landeswahlleiter, many former CDU voters stayed at home, believing the result to be a forgone conclusion. ${ }^{25}$ In addition the party also continued to demonstrate a highly inconsistent level of support in the east and west of the city, still doing best in suburban western areas with a relatively high proportion of older voters. ${ }^{26}$ 
The greatest losses were sustained by the Left Party.PDS, with its overall vote share falling from 22.6 per cent in 2001 to 13.4 per cent. Its losses were most dramatic in the east of the city, falling from an all-time high of 47.6 per cent in 2001, to 28.1 per cent, and from an impressive 6.9 per cent in the west in 2001 to 4.2 per cent. The party's total number of seats fell from 33 to 23, and 18 direct mandates were lost: 14 to the SPD, two to the Greens, one to the CDU, plus one lost through constituency boundary changes. That the party could not repeat its extraordinary performance from 2001 was hardly surprising, but the scale of the losses was unexpected, even among the party leadership. ${ }^{27}$ A variety of factors appear to have contributed to the party's poor showing: firstly, the absence of the 'Gysi factor', which had boosted support in both halves of the city five years previously; secondly, disappointment with the role of the Left Party.PDS in the redred coalition, largely due to cutbacks in public services that had been necessary to reduce the capital's debts; and thirdly, the fact that WASG stood against the Left Party.PDS instead of joining forces as had been the case for the 2005 federal election. In its own evaluation, the Berlin party leadership blamed the following factors: insufficient preparation for government in 2001; appearing to be subordinate to the SPD as junior coalition partner; increased pressure to 'play by the rules' and to behave like a 'normal' party as part of the governing coalition; lack of support from the federal party for its role in government; and not surprisingly, competition from the WASG. ${ }^{28}$ There was also internal criticism that the campaign, led by the party chair, the chair of the Fraktion and the Spitzenkandidat, had been too male dominated, since all three were men. ${ }^{29}$ The Landeswahlleiter believed a large number of former PDS voters had stayed at home on the day of the election, thereby making a substantial contribution to the overall fall in turnout. $^{30}$ Even so, the Left Party.PDS could still count on the support of many older voters in the east of the city, whereas its supporters in the west tended to be very young voters. ${ }^{31}$ However in real terms, five years in government had done little to consolidate the party's support in the west. ${ }^{32}$

The FDP failed to capitalise on the CDU's weak profile and its vote share fell from 9.9 to 7.6 per cent, and its seats from 15 to 13. Losses were greatest in the West, with its vote share falling from 12.8 per cent to 9.3 per cent, in the East from 5.3 to 4.9 per cent. It seems highly likely that potential FDP voters believed that there was no chance of a bourgeois coalition due to the weakness of the CDU, hence there was little point in voting for the Liberals, who had been virtually invisible in Berlin politics since the 1980s.

As mentioned above, the biggest surprise on election night was the performance of various small parties without representation in the Berlin Land parliament who between them polled 13.9 per cent. Added to the 42 per cent of Berliners who did not vote at all, nearly 56 per cent of voters did not support any of the parliamentary parties. The best performance was by the pensioners' party Die Grauen, securing 3.8 per cent of the vote (4.4 in the West and 3 per cent in the east), whose success correlated with loses for the CDU and FDP. ${ }^{33}$ The WASG achieved 2.9 per cent (2.7 in the West, 3.3 in the East). In terms of vote share the WASG's result correlates with the Left Party.PDS's losses in western Berlin, but not in the East where the Left party.PDS lost far more votes than the WASG gained. Finally, far right wing parties made little impact in the election, with the NPD polling 2.6 per cent and the Republikaner polling 0.9 per cent.

\section{COALITION FORMATION}


The mathematics of the election result gave the SPD the choice of either a red-red or a red-green coalition, either of which would have a majority of only three seats in the Berlin parliament. As mentioned earlier, senior SPD figures were believed to have a preference for another coalition with the Left Party.PDS, but had not ruled out the possibility of a coalition with the Greens, hence both parties were invited for exploratory talks with the SPD, and both accepted. For the Greens, at the time not represented in any Land governments in the Federal Republic, this was a great opportunity, and after two rounds of talks with the SPD, leading figures within the party were optimistic. But after talks with the Left Party.PDS the SPD leadership decided to open formal coalition negotiations with the latter. Wowereit's justification for this decision was the good work of the red-red coalition during the previous term and the need for a reliable coalition partner, especially in view of the slim majority either coalition would have in parliament. $^{34}$

The coalition negotiations, led by Wowereit for the SPD and Harold Wolf for the Left Party.PDS, lasted over a month, with student fees and publicly funded job creation projects among the most contentious issues. Also, the parties were waiting for the Federal Constitutional Court to rule on Berlin's plea for more federal financial assistance before they could agree on the future of the city's finances. However, the ruling on 19 October went against the city, ${ }^{35}$ forcing the two parties to include yet more austerity measures in their coalition agreement, such as tax rises, a future reduction in the size of the Land parliament, and the cancellation of Land funding for projects such as the Kanzler U-Bahn and the controversial rebuilding of the Stadtschloss on the site of the Volkskammer of the GDR (though the latter decision was later reversed). Other aspects of the coalition agreement included free day-care for children, plans for comprehensive schools, more advice for the unemployed, renewed efforts to fight against right-wing extremism, and support for a second attempt at a formal merger between Berlin and Brandenburg. ${ }^{36}$ The coalition agreement was finally signed on 20 November 2006, following approval by both parties.

According to the Land constitution, Berlin's governing mayor must be formally voted into office by the Land parliament, but when this took place on 23 November Wowereit required two ballots to be elected, indicating that not only the new 'Jamaica opposition' had voted against him but also some members of the red-red coalition. Previously each nominee for the Berlin Senate also required parliamentary approval but following recent constitutional changes the power to 'hire and fire' now resides with the governing mayor who has also acquired Richtlinienkompetenz similar to that possessed by the German chancellor, thus strengthening the position. ${ }^{37}$ Once in office Wowereit appointed five SPD senators and three from the Left Party.PDS. ${ }^{38}$

While the 2006 Land election was an easy win for the SPD, and a close shave for the Left Party.PDS, the real challenge for both parties began after the election, namely how to tackle Berlin's long-standing financial problems, especially in light of the Federal Constitutional Court's decision regarding financial aid.

CONCLUSION 
While the 2006 Berlin election lacked the drama of the previous Land election, and the result was unlikely to affect the federal government's majority in the Bundesrat, it was still of significance for German politics as a whole due to the further credibility the outcome conferred on the Left Party.PDS. While the latter's entry into government beyond the five new Länder in 2001 was an important milestone for them, being returned to office for a second term was also significant.

In terms of what the election tells us about how united the capital is 16 years after reunification, the conclusions are mixed. While the results showed a very slight convergence in voting patterns in the east and west of the city compared with previous elections, only two parties appear to be firmly anchored in the whole of Berlin, namely the SPD and to a lesser extent, the Greens, but the same cannot be said for the CDU, FDP or the Left Party.PDS (see Table 2). ${ }^{39}$ While objective statistical data suggests that the quality of life for east and west Berliners is becoming increasingly similar, subjective perceptions lag way behind, with only 38 per cent of Berliners believing the city is truly unified, ${ }^{40}$ which, may still have an impact on voting behaviour. But contemporary Berlin is not neatly divided between a rich western half and a depressed eastern half - both sides have more prosperous and more deprived areas - and clearer distinctions are emerging between the inner-city and out-lying areas in both cases. But overall, in view of the city's huge debts, high unemployment and diverse communities, the new red-red senate faces many challenges as it seeks to govern one of Europe's poorest but sexiest capitals.

TABLE 1

BERLIN ELECTION RESULTS 2006 AND 2001

$\begin{array}{lllll}\text { Party } & \text { Result 2006 (\%) } & \text { Seats } 2006 & \text { Result 2001 (\%) } & \text { Seats } 2001 \\ \text { SPD } & 30.8 & 53 & 29.7 & 44 \\ \text { CDU } & 21.3 & 37 & 23.8 & 35 \\ \text { Left.PDS } & 13.4 & 23 & 22.6 & 33 \\ \text { Greens } & 13.1 & 23 & 9.1 & 14 \\ \text { FDP } & 7.6 & 13 & 9.9 & 15 \\ \text { Others } & 13.8 & 0 & 4.9 & 0\end{array}$

TABLE 2

PERCENTAGE RESULTS OF THE 2006 LAND ELECTION

(EAST AND WEST BERLIN)

$\begin{array}{lll}\text { Party } & \text { West } & \text { East } \\ \text { SPD } & 31.4 & 29.8 \\ \text { CDU } & 27.7 & 11.4 \\ \text { Left Party.PDS } & 4.2 & 28.1\end{array}$




$\begin{array}{lll}\text { Greens } & 14.8 & 10.5 \\ \text { FDP } & 9.3 & 4.9 \\ \text { Others } & 12.6 & 15.3\end{array}$

\section{NOTES}

\footnotetext{
${ }^{1}$ For a detailed analysis see Joanna McKay, 'From Pariah to Power: The Berlin Election of 2001 and the PDS Question’, German Politics, 11/2 (2002), pp.21-38.

${ }^{2}$ For example, political scientist, Oskar Niedermayer of the Freie Universität. See 'Geteiltes Empfinden’, Der Tagespiegel, 16 September 2006.

3 'Wir wollen ein liberales Element einbringen', Der Tagespiegel, 26 August 2006.

4 'SPD findet Wahlkampf mit Grass in Ordnung', Der Tagesspiegel, 24 August 2006.

5 'Für Rot-Rot könnte es knapp werden', Der Tagespiegel, 17 September 2006.

6 'Poor but sexy', The Economist, 21 September 2006.

${ }^{7} 17.1$ per cent in September 2006. Source: Bundesagentur fuer Arbeit.

8 'Parteistrategen halten fast jede Koalition für möglich’, Der Tagesspiegel, 22 August 2006.

${ }^{9}$ For example, Oskar Niedermayer, ‘Geteiltes Empfinden’, Der Tagespiegel, 16 September 2006.

10 'Für Rot-Rot könnte es knapp werden', Der Tagespiegel, 17 September 2006.

${ }^{11}$ According to PDS parliamentary party leader, Stefan Liebich. 'Rot-Rot lobt sich - Opposition spricht von versagen’, Der Tagesspiegel, 1 September 2006.

12 'Für Rot-Rot könnte es knapp werden’, Der Tagespiegel, 17 September 2006.

${ }^{13}$ www.friedbert-pflueger.de/NeU/index.htm

${ }^{14}$ Berlin kann mehr. Wahlprogramm der CDU Berlin zur Wahl des Berliner Abgeordnetenhauses am 17. September 2006. www.friedbert-pflueger.de/NeU/index.htm

${ }^{15}$ www.friedbert-pflueger.de/NeU/index.htm

16 'Parteistrategen halten fast jede Koalition für möglich’, Der Tagesspiegel, 22 August 2006.

17 'Parteistrategen halten fast jede Koalition für möglich’, Der Tagesspiegel, 22 August 2006.

18 'Für Rot-Rot könnte es knapp werden', Der Tagespiegel, 17 September 2006.

${ }^{19}$ Kirstin Böttner, 'Rückblick auf den berlingrünen Wahlkampf 2006', Stachlige Argumente 5/2006, p. 18.

20 'Für Rot-Rot könnte es knapp werden', Der Tagespiegel, 17 September 2006.

${ }^{21}$ All election results are from the Landeswahlleiter fuer Berlin. The number of seats in the Berlin parliament rose from in 141 in 2001 to 149 in 2006, with the number of list seats rising from 63 to 71 . The number of direct mandates remained constant at 78, but there were minor boundary changes. An additional constituency was added to both Pankow and Tempelhof-Schöneberg, while Mitte and Lichtenberg both lost one.

${ }^{22}$ The Greens' total share of the votes increased by 33,000.

${ }^{23}$ Sebastian Bukow, 'Grün gewählt?’ Stachlige Argumente 5/2006, p.7.

${ }^{24}$ Der Landeswahlleiter, Wahlen in Berlin am 17. September 2006, p.119.

${ }^{25}$ Der Landeswahlleiter, Wahlen in Berlin, p.101.

${ }^{26}$ Der Landeswahlleiter, Wahlen in Berlin, p.119.

${ }^{27}$ Die Linke.PDS Berlin: Nach der Wahl, 19 September 2006. www.linkspartei-

berlin.de/politik/positionen/partei/strategiedebatte/nach_der_wahl/

${ }^{28}$ Die Linkspartei.PDS. Beiträge zur Wahlauswertung, 8 December 2006, pp.3-10. www.linksparteiberlin.de/wahlen/wahl_2006/forum_wahlanalyse

${ }^{29}$ They were Land party chair, Klaus Lederer, parliamentary party leader, Stefan Liebich, and Spitzenkandidat, Harald Wolf. 'Weibliche Verstärkung für PDS-Boygroup', Der Tagespiegel, 10 October 2006.

${ }^{30}$ Der Landeswahlleiter, Wahlen in Berlin, p.101.

${ }^{31}$ Der Landeswahlleiter, Wahlen in Berlin, p.119.

${ }^{32}$ Der Landeswahlleiter, Wahlen in Berlin, p.104.
} 
${ }^{33}$ Der Landeswahlleiter, Wahlen in Berlin, p.123.

34 'In Berlin stehen alle Zeichen auf Rot-Rot', Der Tagesspiegel, 30 September 2006.

35 'Berlin muss es alleine schaffen', Der Tagesspiegel, 20 October 2006.

${ }^{36}$ The full text of the coalition agreement can be found at

www.berlin.de/rbmskzl/koalitionsvereinbarung/index.html

37 'Berlins Bürgermeister wird mächtig wie nie zuvor’, Der Tagesspiegel, 23 November 2006.

${ }^{38}$ www.berlin.de/rbmskzl/rbm/senat.html

${ }^{39}$ Der Landeswahlleiter, Wahlen in Berlin, p.104.

40 'Die Zahlen sprechen für die Einheit', Der Tagesspiegel, 2 October 2006. 